\title{
Genetic Analysis of Advanced Populations in Antirrhinum majus L. with Special Reference to Cut Flower Postharvest Longevity
}

\author{
William J. Martin ${ }^{1}$ and Dennis P. Stimart ${ }^{2}$ \\ Department of Horticulture, University of Wisconsin-Madison, 1575 Linden Drive, Madison, \\ WI 53706
}

\begin{abstract}
AdDitional INDEX wORDs. vase life, postharvest keeping quality, narrow-sense heritability, genetic correlation, phenotypic correlation, selection

Abstract. Narrow-sense heritabilities and genetic correlations of ornamental quality traits of Antirrhinum majus (snapdragon) were evaluated with special reference to cut flower postharvest longevity (PHL). Inbreds P1 (16 days PHL) and $P 2$ (3 days PHL) were hybridized to produce an $F_{1}(P 1 \times P 2)$ that was self-pollinated to produce an $F_{2}$ population. The $F_{2}$ were self-pollinated to produce $F_{3}$ families and advanced through single-seed descent by self-pollination to the $F_{5}$ generation. P1, P2, $F_{1}, F_{3}, F_{4}$, and $F_{5}$ were evaluated for ornamental quality traits. Quality traits were found to be quantitative and normally distributed. Narrow-sense heritability $\left(h^{2}\right)$ estimates were high and consistent across generations examined; PHL $h^{2}$ ranged from 0.79 to $0.81 \pm 0.06$. Phenotypic and genotypic correlations revealed underlying physiological and pleiotropic interactions relevant to breeding programs aimed at simultaneous improvement of ornamental quality traits. PHL is inversely related to cut flower strength and days to flower, $-0.44 \pm 0.04$ and $-0.43 \pm 0.44$. Buds at discard is positively correlated to cut flower and plant diameter, cut flower weight and days to flower, $0.77 \pm 0.05,0.58$ $\pm 0.06,0.71 \pm 0.06$, and $0.77 \pm 0.07$, respectively. Gain from selection for quality traits of interest can be rapid.
\end{abstract}

Crop quality is usually complexly defined and component traits are often quantitative in nature. In ornamentals, cut flower quality is defined by characteristics of plant and floral architecture as well as cut flower postharvest longevity (PHL). Reports attempt to alter architecture and PHL through chemical remediation but are often met with limited success. In addition, chemicals available to industry are becoming limited due to safety concerns (Nell, 1992; Ohkawa et al., 1999). Classic breeding techniques provide an alternative to chemical remedies for advancement of quantitative trait quality in ornamentals.

Quantitative trait heritability information is useful to breeding programs to best design evaluation and selection strategies. Common in agronomic crops, this information is rare in ornamentals. Variability within quantitative quality traits has been noted in many ornamental species, but application of this information in breeding programs is limited. Recent breeding advances in cut flower quality include selection response against stem bending, folding and wilting (Wernett et al., 1996a) and for an increase in number of flowering stems (Harding et al., 1981). Successful selection in Dianthus caryophyllus L. (carnation) for PHL was recently described by Burchi et al. (1999) and Onozaki et al. (2001).

Antirrhinum majus is an important cut flower, however, little is known about genetics of its ornamental quality traits. Preliminary work in A. majus revealed PHL as quantitative with significant additive and dominant genetic variance components (Schroeder and Stimart, 2001). In addition, PHL can be manipulated in populations (Schroeder, 1995).

Received for publication 3 June 2004. Accepted for publication 19 Aug. 2004. A note of gratitude to Dr. Erik Nordheim, Univ. of Wisconsin-Madison, for statistical consultation during preparation of this manuscript. Use of trade names does not imply endorsement of the products named or criticism of similar ones not named.

${ }^{1}$ Research Assistant

${ }^{2}$ Professor and Chair of Dept. To whom reprint requests should be addressed. Email address: dstimart@wisc.edu
Inheritance of ornamental quality traits and correlations between traits were investigated to provide a foundation to advance quality in A. majus cut flowers through classic breeding methodology with a goal of expanding crop market share. Work presented here provides trait heritability and correlational information relevant to breeding for plant architectural, production, and cut flower quality traits. Emphasis is placed on PHL and correlated traits.

\section{Materials and Methods}

Commercial inbred lines of Antirrhinum majus cut flower types were evaluated for cut flower PHL in 1991 and 1992 at the Univ. of Wisconsin-Madison (Stieve and Stimart, 1994). Two white-flowered lines selected represented observed extremes in PHL, P1 (16.3 d PHL) and P2 (3.0 d PHL) (Stieve and Stimart, 1994). P1 and P2 were self-pollinated for five generations and hybridized to produce $\mathrm{F}_{1}(\mathrm{P} 1 \times \mathrm{P} 2)$. The $\mathrm{F}_{1}$ was self-pollinated to produce an $F_{2}$ in Fall 1998. From the $F_{2}, 485$ plants were randomly selected and self-pollinated to produce $\mathrm{F}_{3}$ families. A total of 155 randomly selected $\mathrm{F}_{3}$ families were advanced through single-seed descent to the $\mathrm{F}_{5}$. Seed set and germination failures resulted in loss of 19 families, $12 \%$ of the population, by the $\mathrm{F}_{4}$; and 4 families, $3 \%$ of the population, by the $\mathrm{F}_{5}$. Thus, 132 $\mathrm{F}_{3}, \mathrm{~F}_{4}$, and $\mathrm{F}_{5}$ families remained with 110 randomly selected for evaluation. Poor germination in the 110 families being evaluated resulted in $4 \%$ reduction of the population.

$\mathrm{P} 1, \mathrm{P} 2, \mathrm{~F}_{1}, \mathrm{~F}_{3}, \mathrm{~F}_{4}$, and $\mathrm{F}_{5}$ plants were grown in Fall, Winter, and Spring 2001-2002 in three replicated plantings using a randomized complete-block design (six blocks fall and spring, nine blocks winter, one rep/genotype/block) in a polyhouse at the Univ. of Wisconsin-Madison according to standard forcing procedures (Rogers, 1992). Briefly, seeds were germinated in a cell of a cell pack and seedlings individually transplanted to 96 -cell $\left(65 \mathrm{~cm}^{3}\right)$ flats as the first pair of true leaves emerged. Seedlings were trans- 
planted to square plastic pots $\left(1250 \mathrm{~cm}^{3}\right)$ when the third to fourth set of true leaves appeared and grown through anthesis. Growing medium was equal volumes of soil, peat, and perlite. Plant bench spacing was on $22-\mathrm{cm}$ centers. Plants were fertilized every other week with $200 \mathrm{mg} \cdot \mathrm{L}^{-1} \mathrm{~N}$ using Peter's 20N-8.7P-16.6K (Scott's Sierra, Marysville, Ohio) and provided supplemental light of 27 $\mu \mathrm{mol} \cdot \mathrm{m}^{-2} \cdot \mathrm{s}^{-1}$ at bench level using $1000-\mathrm{W}$ high-pressure sodium lamps from 0600 through $2400 \mathrm{HR}$.

Whole plants were harvested for evaluation when the first five florets opened thereby equalizing developmental stage. Plants were immediately placed in distilled water $\left(\mathrm{dH}_{2} \mathrm{O}\right)$ and transported to the laboratory. Plant height and lowest floret height, termed plant height nonfloral, were noted and floral region size was derived from their difference. Plant weight and basal plant diameter were recorded. Plant architecture, termed branching habit, was evaluated on a numeric scale based on commercial preference (L. Laughner, personal communication). Branching habit score was obtained by taking the sum of branching habit code multiplied by the number of nodes where branching occurred, $\sum \mathrm{k}_{\mathrm{i}} \mathrm{n}_{\mathrm{i}}$; where $\mathrm{k}=1$ (side branching $<10 \mathrm{~cm}$ in length), 2 (basal branching), 3 (side branching $>10 \mathrm{~cm}$ in length), 4 (crown branching), or 5 (branching with buds), and $n=$ number of nodes where branching occurred. Number of florets at harvest showing color before anthesis, termed buds at harvest, was recorded. At harvest, floral region uniformity was rated on a visual scale $(1=$ excellent to $5=$ very poor, Fig. 1 ), and floral region density was derived by adding number of open florets and buds and dividing by floral region size. The width of a leaf from $\approx 40 \mathrm{~cm}$ below lowest floret was recorded.

Stems were adjusted to a length of $40 \mathrm{~cm}$ below the lowest floret and the bottom $15 \mathrm{~cm}$ of leaves from the stem were removed; the inflorescence and supporting stem are hereafter termed cut flower. Cut flower weight and basal cut flower diameter were recorded. Cut flower strength was assessed as deviation in $\mathrm{cm}$ at cut flower tip when holding the basal $5 \mathrm{~cm}$ of cut flower stem horizontal. Fifteen cut flowers were arranged in a three by five rectangular arrangement, stems placed 7.5 $\mathrm{cm}$ apart, supported upright with a wire mesh in plastic storage containers $34 \times 22 \times$ $15 \mathrm{~cm}(\mathrm{~L} \times \mathrm{W} \times \mathrm{H})$ containing, at a depth of $4 \mathrm{~cm}, 3 \mathrm{~L}$ of $\mathrm{dH}_{2} \mathrm{O}$. Holding solutions were maintained daily by addition of $\mathrm{dH}_{2} \mathrm{O}$. PHL evaluation utilized a completely random design. Cut flowers were evaluated at $23{ }^{\circ} \mathrm{C}$ under continuous cool-white fluorescent illumination of $11 \mu \mathrm{mol} \cdot \mathrm{m}^{-2} \cdot \mathrm{s}^{-1}$ at bench level. Cut flower senescence was defined as $50 \%$ of the florets browning/drying or wilting (Marousky and Raulston, 1970). At cut flower discard, numbers of buds, defined above, and open florets were recorded. Number of florets opening after harvest was derived by subtracting florets open at harvest, five, from number of open florets at discard. Dates of seed sowing, plant harvest, and cut flower senescence were recorded; days to flower and cut flower PHL were derived from their differences.

Due to logistic limitations, cut flower leaf area, stoma per area and stomatal index, $\{[$ (number of stoma / number of stoma + number of epidermal cells) per area] $\times 100\}$
(Salisbury, 1927 as referenced by Lea et al., 1977), were obtained from the winter planting on cut flowers from three blocks. Cut flower leaf area was determined using a LI-COR 3100 area meter (LI-COR, Lincoln, Nebr.) by destructively sampling three cut flowers of each genotype. Stoma per area and stomatal index were assessed by using abaxial leaf imprints created in super glue on glass microscope slides (Sampson, 1961). Fully expanded leaves from the third node above soil line were sampled destructively 8 weeks after seed sowing from three plants of $F_{3}, F_{4}$, and $F_{5}$ families. One image, $0.24 \mu \mathrm{m}^{2}$, was collected digitally from the distal one-third of each imprint using iMovie (Apple Computer, Cupertino, Calif.) and analyzed using Adobe Photoshop 5.5 (Adobe Systems, San Jose, Calif.).

Population statistics, including generational means, minimums, maximums, and standard deviations; data transformations; and generation mean separations by LSD were generated by the SAS statistical package (Littell et al., 1996). Resolution of components of variance was completed assuming a completely random design in SAS mixed models analysis with Satterthwaite corrections for degrees of freedom (Satterthwaite, 1946). Narrow-sense heritability estimates for traits measured in three plantings were calculated (Hallauer and Miranda, 1988) with 95\% confidence intervals (CI) calculated according to Knapp et al. (1985). Narrow-sense heritability estimates for traits measured in three plantings were confirmed via parent-offspring regression (Falconer and Mackay, 1996). Narrow-sense heritability and standard error estimates of traits measured in one planting were determined via parent-offspring regression (Falconer and Mackay, 1996).

Phenotypic and genotypic correlation coefficients were calculated utilizing the SAS statistical package (Littell et al., 1996). Trait correlations from inbred lines are considered most accurate due to minimal effects of dominance and environmental variance bias (Falconer and Mackay, 1996). Therefore, $F_{5}$ genotypic and phenotypic correlation coefficients are presented. Phenotypic correlations can be subject to large environmental correlations (Falconer and Mackay, 1996), therefore, focus will be on signifi-

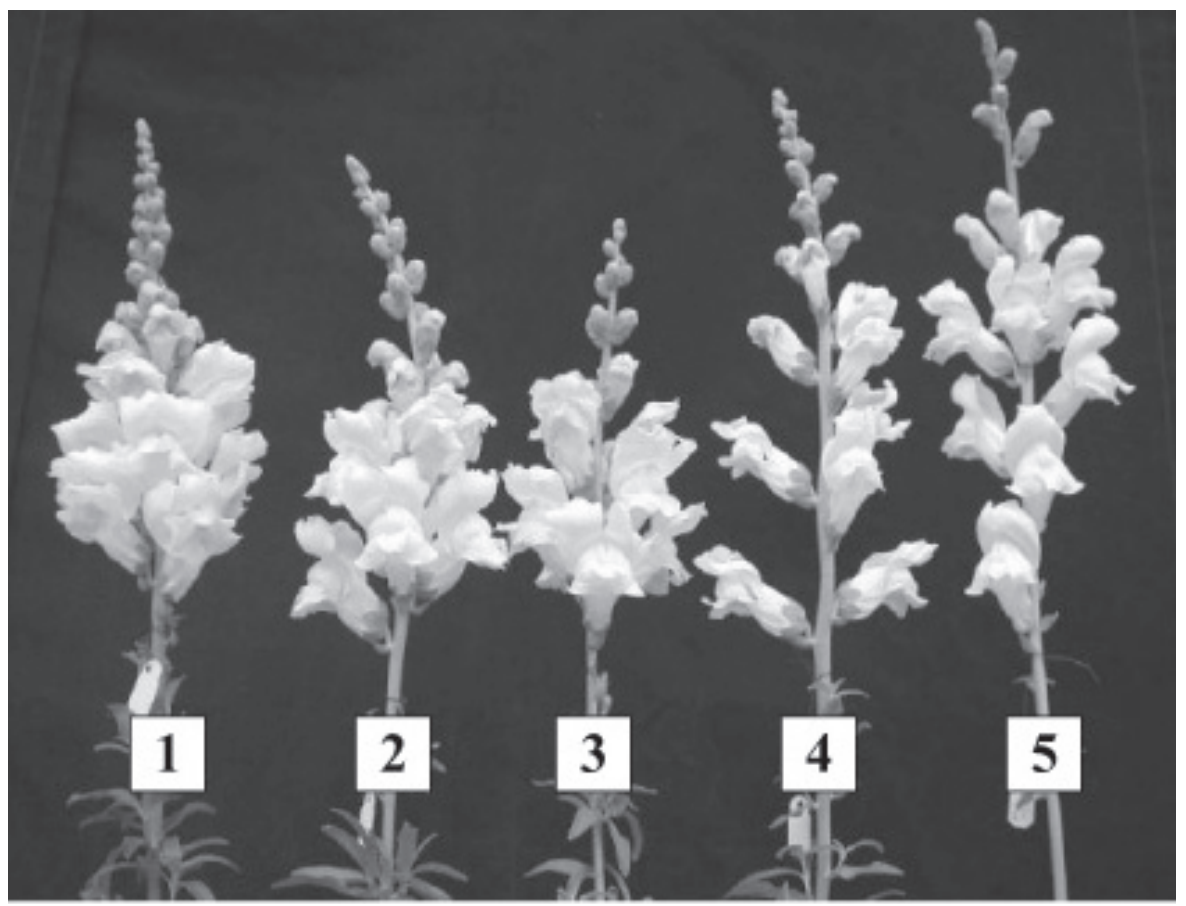

Fig. 1. Visual scale of floret uniformity for Antirrhinum majus. 
cant genotypic correlations with values of $r>0.35$. This value is conservatively chosen as the minimum level of significant correlation with $100 \mathrm{df}(0.25)$ plus the largest standard error observed among the genetic correlations, +0.10 . Genotypic correlations between traits measured in one planting and traits measured in three plantings were inestimable (Falconer and Mackay, 1996).

\section{Results and Discussion}

Cut flower and whole plant distributions for 22 evaluated traits are continuous and normal with exception of cut flower senescence symptom. Transformations of cut flower senescence symptom data had no effect upon subsequent analysis; therefore, raw data results are presented. Generation means are not significantly different for all traits examined with exception of days to flower (Fig. 2, Table 1). Mean days to flower for $\mathrm{F}_{5}$ is significantly later than for $\mathrm{F}_{3}$ while the $\mathrm{F}_{4}$ mean, intermediate to $\mathrm{F}_{3}$ and $\mathrm{F}_{5}$, is not significantly different from either (Fig. 2, Table 1). A significant shift in population mean signifies associated inbreeding depression with the trait (Falconer and Mackay, 1996).

Inbreeding depression, due to exposure of deleterious reproductive fitness alleles in the population, is expected if dominance exists for the trait but is rarely seen in naturally selfing species (Falconer and Mackay, 1996). Days to flower; and flower number, size, and nectar production directly affect reproductive fitness in Penstemon centranthifolius Benth. (scarlet bugler) (Mitchell and Shaw, 1993) a member of same plant family (Scrophulariaceae) as A. majus. Nectar production and flower size were not analyzed in A. majus and non-flowering genotypes were eliminated during population development. Dominance for days to flower has been reported in Helianthus annиит L. (sunflower) cultivars (Virk and Pooni, 1994) and A. majus days to flower inbreeding depression supports existence of dominance variance. Lack of inbreeding depression in A. majus is expected because the species can naturally self-pollinate and the examined traits in this study, with the exception of days to flower, do not affect reproductive biology. Inbreeding depression has been reported for quantitative traits in outcrossing species including Dendrobium sp. Sw. (orchid) (Bobisud and Kamemoto, 1982), Solanum tuberosum L. (potato) (Bradshaw et al., 2000), and Zea mays L. (maize) (Hallauer and Sears, 1973); however, inbreeding depression was not found in naturally self-pollinating Lupinus harvardii Wats. (bluebonnet) (Mackay and Davis, 1998).

Dominance in A. majus PHL has been shown by analyses of generation means and hybrid populations (Martin, 2000; Schroeder and Stimart, 2001) but was not confirmed by analysis of this recombinant inbred population. Loss of families during population development could cause lack of observed inbreeding depression by purging deleterious alleles. Exploitation of dominance variance may be beneficial to hybrid production (Schroeder and Stimart, 2001). However, if released cultivars are inbred lines, exploitation of dominance variance may not be as important as previously thought for commercially important plant and cut flower traits.

Narrow-sense heritabilities, $\mathrm{h}^{2}$, and respective confidence intervals for $\mathrm{F}_{3}, \mathrm{~F}_{4}$, and $\mathrm{F}_{5}$ family traits measured in three plantings range from $0.20(\mathrm{CI}=-0.05$ to 0.39$)$ to $0.88(\mathrm{CI}=0.85$ to 0.91) (Table 2). All traits were highly heritable in $F_{5}$ families, ranging from 0.63 to $0.88( \pm 0.10)$ with exceptions of branching habit $(0.41, \mathrm{CI}=0.23$ to 0.55$)$ and buds at discard $(0.20, \mathrm{CI}=$ -0.05 to 0.39 ). Heritabilities for cut flower leaf area, stoma and stomatal index, each examined in the winter planting, are moderate to low for $\mathrm{F}_{3}, \mathrm{~F}_{4}$, and $\mathrm{F}_{5}$ families. Narrow-sense heritability estimates from parent-offspring regression for traits measured in three plantings are lower than estimates derived from analy-

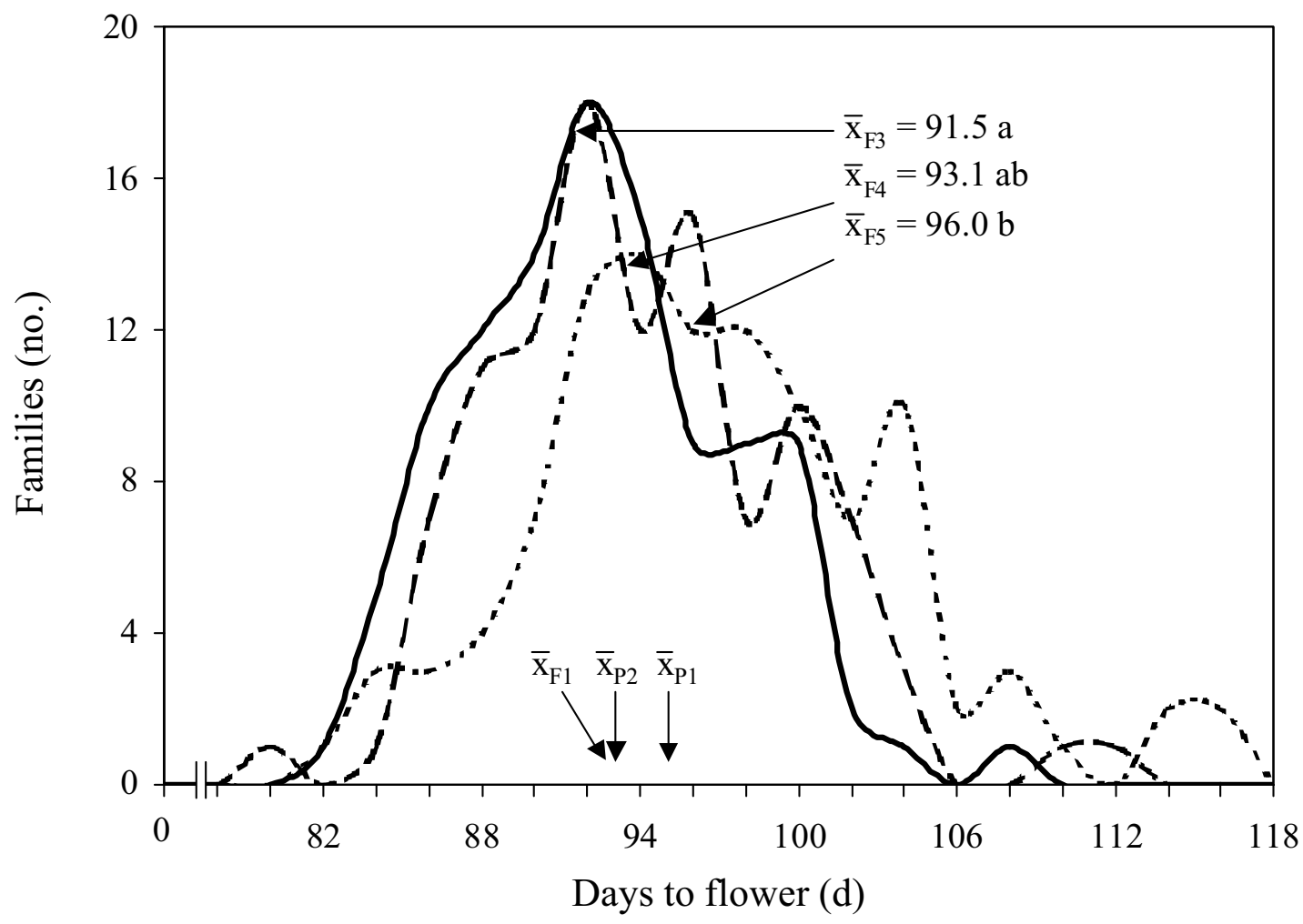

Fig. 2. Days to flower for inbred lines $\mathrm{P} 1$ and $\mathrm{P} 2, \mathrm{~F}_{1}(\mathrm{P} 1 \times \mathrm{P} 2)$, and $105 \mathrm{~F}_{3}(-), \mathrm{F}_{4}(--)$ and $\mathrm{F}_{5}(\bullet \bullet \bullet)$ families of Antirrhinum majus. $\mathrm{x}=$ group mean. Mean separation by LSD, $P<0.05$. 
Table 1. Population statistics for phenotypic traits of $\mathrm{F}_{3}, \mathrm{~F}_{4}$, and $\mathrm{F}_{5}$ families in Antirrhinum majus.

\begin{tabular}{|c|c|c|c|c|c|c|c|c|c|c|c|c|}
\hline \multirow[b]{2}{*}{ Phenotypic trait } & \multicolumn{4}{|c|}{$\mathrm{F}_{3}$} & \multicolumn{4}{|c|}{$\mathrm{F}_{4}$} & \multicolumn{4}{|c|}{$\mathrm{F}_{5}$} \\
\hline & Mean $^{z}$ & Min. & Max. & SD & Mean $^{\mathrm{Z}}$ & Min. & Max. & SD & Mean $^{z}$ & Min. & Max. & SD \\
\hline Branching habit $^{y}$ & 15.0 & 6.3 & 25.3 & 4.1 & 14.1 & 3.8 & 29.1 & 4. & 14.7 & 2.3 & 29.9 & 5.2 \\
\hline Buds at discard (no.) ${ }^{\mathrm{x}}$ & 4.5 & 1.4 & 12.4 & 1.5 & 4.4 & 1.1 & 9.4 & 1.5 & 4.2 & 0.6 & 7.7 & 1.4 \\
\hline Buds at harvest (no.) ${ }^{\mathrm{x}}$ & 17.0 & 11.2 & 22.8 & 2.3 & 16.6 & 8.9 & 24.4 & 2.9 & 16.4 & 7.8 & 25.9 & 3.2 \\
\hline Cut flower diameter $(\mathrm{mm})^{\mathrm{w}}$ & 4.2 & 3.2 & 5.9 & 0.6 & 4.2 & 2.7 & 6.2 & 0.7 & 4.1 & 2.7 & 6.2 & 0.8 \\
\hline Cut flower leaf area $\left(\mathrm{cm}^{2}\right)^{v}$ & 130.2 & 50.3 & 273.0 & 51.6 & 135.6 & 24.2 & 461.0 & 70.4 & 134.1 & 26.0 & 450.4 & 64.0 \\
\hline Cut flower strength $(-\mathrm{cm})^{\mathrm{u}}$ & 9.4 & 2.9 & 20.9 & 3.4 & 9.1 & 1.3 & 20.3 & 3.9 & 9.2 & 0.5 & 17.2 & 3.9 \\
\hline Cut flower weight $(\mathrm{g})^{\mathrm{v}}$ & 18.6 & 12.2 & 28.2 & 3.3 & 18.7 & 11.1 & 35.2 & 4.3 & 18.5 & 12.1 & 39.0 & 4.8 \\
\hline Days to flower (d) ${ }^{t}$ & $91.5 \mathrm{a}$ & 81.7 & 107.0 & 5.2 & $93.1 \mathrm{ab}$ & 79.6 & 111.1 & 5.6 & $96.0 \mathrm{~b}$ & 80.7 & 114.4 & 6.8 \\
\hline Floral region density ${ }^{\mathrm{s}}$ & 0.9 & 0.6 & 1.4 & 0.1 & 0.9 & 0.6 & 2.1 & 0.2 & 1.0 & 0.6 & 2.9 & 0.3 \\
\hline Floral region size $(\mathrm{cm})^{\mathrm{r}}$ & 19.3 & 12.7 & 26.8 & 2.6 & 18.9 & 11.2 & 27.4 & 3.3 & 18.0 & 8.2 & 27.1 & 3.7 \\
\hline Floral region uniformity ${ }^{\mathrm{q}}$ & 3.1 & 1.8 & 4.1 & 0.4 & 3.1 & 1.6 & 4.4 & 0.5 & 3.1 & 1.8 & 4.1 & 0.4 \\
\hline Florets open at discard (no.) & 14.2 & 9.5 & 17.8 & 1.7 & 13.7 & 7.3 & 20.6 & 2.3 & 13.5 & 7.2 & 19.7 & 2.4 \\
\hline Florets opening (no.) $)^{p}$ & 9.3 & 4.8 & 13.7 & 1.7 & 8.9 & 2.4 & 15.6 & 2.2 & 8.6 & 3.2 & 14.7 & 2.3 \\
\hline Leaf width $(\mathrm{cm})^{\mathrm{w}}$ & 2.2 & 1.6 & 4.0 & 0.4 & 2.3 & 1.2 & 3.7 & 0.4 & 2.3 & 1.3 & 3.8 & 0.5 \\
\hline Plant diameter $(\mathrm{mm})^{\circ}$ & 4.1 & 3.1 & 5.4 & 0.5 & 4.0 & 2.8 & 5.5 & 0.6 & 3.9 & 2.5 & 6.7 & 0.7 \\
\hline Plant height $(\mathrm{cm})^{\mathrm{n}}$ & 90.0 & 58.3 & 122.2 & 11.3 & 88.5 & 56.1 & 128.5 & 14.4 & 86.5 & 55.6 & 124.4 & 15.1 \\
\hline Plant height nonfloral $(\mathrm{cm})^{\mathrm{m}}$ & 70.7 & 44.6 & 102.8 & 10.5 & 69.6 & 42.1 & 109.0 & 12.6 & 68.5 & 42.5 & 101.8 & 13.3 \\
\hline Plant weight $(\mathrm{g})^{\mathrm{n}}$ & 49.0 & 27.5 & 66.5 & 8.9 & 48.5 & 26.1 & 74.0 & 10.1 & 48.9 & 20.0 & 84.1 & 11.2 \\
\hline Postharvest longevity (d) ${ }^{1}$ & 11.5 & 6.1 & 16.1 & 2.1 & 10.9 & 4.9 & 16.4 & 2.5 & 10.8 & 4.8 & 16.8 & 2.7 \\
\hline Senescence symptom ${ }^{\mathrm{k}}$ & 0.8 & 0.2 & 1.0 & 0.2 & 0.7 & 0.0 & 1.0 & 0.3 & 0.7 & 0.2 & 1.0 & 0. \\
\hline Stoma (no.) & 42.4 & 22.0 & 70.0 & 9.0 & 40.4 & 22.7 & 62.0 & 9.4 & 39.9 & 23.3 & 62.3 & $8 .^{\prime}$ \\
\hline Stomatal index ${ }^{\mathrm{j}}$ & 23.0 & 19.5 & 27.4 & 1.9 & 23.0 & 18.0 & 27.2 & 2.0 & 22.2 & 17.3 & 26.8 & 2. \\
\hline
\end{tabular}

${ }^{z}$ Mean separation by LSD, $P \leq 0.05$. Mean values without letters are not significantly different.

yBranching habit: $\sum \mathrm{k}_{\mathrm{i}} \mathrm{n}_{\mathrm{j}}$; where $\mathrm{k}=1$ (side branching $<10 \mathrm{~cm}$ in length), 2 (basal branching), 3 (side branching $>10 \mathrm{~cm}$ in length, usually singular), 4 (crown branching), or 5 (branching with floral buds) and $n=$ number of nodes where branching occurred.

xFlorets showing color before anthesis.

wAt $40 \mathrm{~cm}$ below lowest floret.

vof $40 \mathrm{~cm}$ stem below lowest floret with bottom $15 \mathrm{~cm}$ of leaves removed.

uneviation in $\mathrm{cm}$ from horizontal position.

t(Date of plant harvest - date of seed sowing).

$\mathrm{s}$ [(Number of buds + number of open florets) / (plant height - plant height nonfloral) at harvest].

$\mathrm{r}$ (Plant height - plant height nonfloral).

qVisual scale $(1$ = excellent, 5 = very poor $)$.

$\mathrm{p}$ (Florets open at discard - florets open at harvest).

oAt soil line.

${ }^{\mathrm{n}}$ Soil line to plant tip.

$\mathrm{m}$ Soil line to lowest floret.

'(Date of cut flower senescence - date of plant harvest).

${ }^{\mathrm{k} W i l t i n g}=0$ or browning/drying $=1$.

$\mathrm{j}$ [Number of stoma / (number of stoma + number of epidermal cells) per area $] \times 100$.

sis of variance (ANOVA) (Table 2). For ANOVA derivation of $\mathrm{h}^{2}$ from data collected on repeated plantings, formulas include mathematical corrections for environmental and genotype-byenvironmental error estimates thereby increasing $\mathrm{h}^{2}$ (Falconer and Mackay, 1996). With this correction, $\mathrm{h}^{2}$ estimates from ANOVA are considered more accurate.
Reduction in heritability with inbreeding may be due to reduced upward bias of dominance variance (Falconer and Mackay, 1996), and significant dominance variance in A. majus was concluded above for days to flower. Therefore, stability of heritability values across generations evaluated is expected and was observed with exceptions of buds at discard and cut flower 
Table 2. Narrow-sense heritability estimates $\left(\mathrm{h}^{2}\right)$ and confidence intervals (CI) or standard errors (SE) for phenotypic traits.

\begin{tabular}{|c|c|c|c|c|c|c|}
\hline Phenotypic trait & $\mathrm{F}_{3} \mathrm{~h}^{2 \mathrm{z}}$ & $\mathrm{CI}^{\mathrm{y}}$ & $\mathrm{F}_{4} \mathrm{~h}^{2}$ & CI & $\mathrm{F}_{5} \mathrm{~h}^{2}$ & CI \\
\hline Branching habit $^{\mathrm{x}}$ & 0.49 & $(0.33,0.61)$ & 0.42 & $(0.24,0.56)$ & 0.41 & $(0.23,0.55)$ \\
\hline Buds at discard (no.) ${ }^{\mathrm{w}}$ & 0.48 & $(0.32,0.60)$ & 0.46 & $(0.29,0.59)$ & 0.20 & $(-0.05,0.39)$ \\
\hline Buds at harvest (no.) ${ }^{\mathrm{w}}$ & 0.73 & $(0.65,0.79)$ & 0.74 & $(0.66,0.80)$ & 0.69 & $(0.60,0.77)$ \\
\hline Cut flower diameter $(\mathrm{mm})^{\mathrm{v}}$ & 0.81 & $(0.75,0.86)$ & 0.73 & $(0.65,0.80)$ & 0.77 & $(0.70,0.82)$ \\
\hline Cut flower strength $(-\mathrm{cm})^{\mathrm{u}}$ & 0.75 & $(0.67,0.81)$ & 0.72 & $(0.64,0.79)$ & 0.69 & $(0.60,0.77)$ \\
\hline Cut flower weight $(\mathrm{g})^{\mathrm{t}}$ & 0.85 & $(0.80,0.88)$ & 0.76 & $(0.69,0.82)$ & 0.80 & $(0.74,0.85)$ \\
\hline Days to flower $(\mathrm{d})^{\mathrm{s}}$ & 0.72 & $(0.63,0.79)$ & 0.63 & $(0.52,0.72)$ & 0.68 & $(0.58,0.75)$ \\
\hline Floral region density ${ }^{\mathrm{r}}$ & 0.69 & $(0.59,0.76)$ & 0.80 & $(0.73,0.84)$ & 0.77 & $(0.69,0.82)$ \\
\hline Floral region size $(\mathrm{cm})^{\mathrm{q}}$ & 0.74 & $(0.65,0.80)$ & 0.73 & $(0.65,0.79)$ & 0.63 & $(0.51,0.72)$ \\
\hline Floral region uniformity ${ }^{p}$ & 0.76 & $(0.69,0.82)$ & 0.78 & $(0.71,0.83)$ & 0.73 & $(0.65,0.80)$ \\
\hline Florets open at discard (no.) & 0.63 & $(0.51,0.72)$ & 0.75 & $(0.67,0.81)$ & 0.72 & $(0.63,0.79)$ \\
\hline Florets opening (no.) ${ }^{\circ}$ & 0.66 & $(0.56,0.74)$ & 0.75 & $(0.67,0.81)$ & 0.71 & $(0.63,0.78)$ \\
\hline Leaf width $(\mathrm{cm})^{\mathrm{v}}$ & 0.73 & $(0.64,0.79)$ & 0.67 & $(0.57,0.75)$ & 0.85 & $(0.80,0.88)$ \\
\hline Plant diameter $(\mathrm{mm})^{\mathrm{n}}$ & 0.83 & $(0.78,0.87)$ & 0.73 & $(0.65,0.80)$ & 0.81 & $(0.76,0.86)$ \\
\hline Plant height $(\mathrm{cm})^{\mathrm{m}}$ & 0.78 & $(0.71,0.83)$ & 0.84 & $(0.79,0.88)$ & 0.84 & $(0.79,0.88)$ \\
\hline Plant height nonfloral $(\mathrm{cm})^{1}$ & 0.82 & $(0.76,0.86)$ & 0.87 & $(0.82,0.90)$ & 0.88 & $(0.85,0.91)$ \\
\hline Plant weight $(\mathrm{g})^{\mathrm{m}}$ & 0.77 & $(0.70,0.82)$ & 0.65 & $(0.54,0.73)$ & 0.73 & $(0.64,0.79)$ \\
\hline Postharvest longevity (d) ${ }^{\mathrm{k}}$ & 0.79 & $(0.73,0.84)$ & 0.81 & $(0.75,0.86)$ & 0.81 & $(0.75,0.86)$ \\
\hline Senescence symptom ${ }^{\mathrm{j}}$ & 0.61 & $(0.49,0.70)$ & 0.75 & $(0.67,0.81)$ & 0.70 & $(0.61,0.77)$ \\
\hline Cut flower leaf area $\left(\mathrm{cm}^{2}\right)^{\mathrm{t}}$ & 0.58 & \pm 0.08 & 0.33 & \pm 0.08 & 0.28 & \pm 0.08 \\
\hline Stoma (no.) & 0.21 & \pm 0.07 & 0.33 & \pm 0.08 & 0.28 & \pm 0.08 \\
\hline Stomatal index ${ }^{\mathrm{g}}$ & 0.21 & \pm 0.07 & 0.14 & \pm 0.07 & 0.21 & \pm 0.08 \\
\hline
\end{tabular}

$\mathrm{zh}^{2}=\left(\sigma_{\mathrm{g}}^{2}\right) /\left(\sigma^{2} / \mathrm{re}+\sigma_{\mathrm{ge}}^{2} / \mathrm{e}+\sigma_{\mathrm{g}}^{2}\right)$, derived from ANOVA.

y95\% CI: $1-\left[\left(\mathrm{F}_{\mathrm{dfG}, \mathrm{dfGxE}}\right) \times\left(\left(\mathrm{MS}_{\mathrm{G}} / \mathrm{MS}_{\mathrm{GxE}}\right) \mathrm{F}_{1-\alpha / 2: \mathrm{dfG} \mathrm{ge}, \mathrm{dfG}}\right)\right]^{-1}$ and 1-[( $\left.\left.\mathrm{F}_{\mathrm{dfG}, \mathrm{dfGxE}}\right) \times\left(\left(\mathrm{MS}_{\mathrm{G}} / \mathrm{MS}_{\mathrm{GxE}}\right) \mathrm{F}_{\alpha / 2: \mathrm{dfGxE}, \mathrm{dfG}}\right)\right]^{-1}$.

Branching habit: $\sum \mathrm{k}_{\mathrm{i}} \mathrm{n}_{\mathrm{j}}$; where $\mathrm{k}=1$ (side branching $<10 \mathrm{~cm}$ in length), 2 (basal branching), 3 (side branching $>10 \mathrm{~cm}$ in length, usually singular),

4 (crown branching), or 5 (branching with buds) and $n=$ number of nodes where branching occurred.

wFlorets showing color before anthesis.

vAt $40 \mathrm{~cm}$ below lowest floret.

uneviation in $\mathrm{cm}$ from horizontal position.

tOf $40 \mathrm{~cm}$ stem below lowest floret with bottom $15 \mathrm{~cm}$ of leaves removed.

s(Date of plant harvest - date of seed sowing).

$\mathrm{r}$ [(Number of buds + number of open florets) / (plant height - plant height nonfloral) at harvest].

$\mathrm{q}($ Plant height - plant height nonfloral).

pVisual scale $(1=$ excellent, $5=$ very poor $)$.

$\circ$ (Florets at cut flower senescence - florets at harvest).

nAt soil line.

mSoil line to plant tip.

${ }^{1}$ Soil line to lowest floret.

$\mathrm{k}$ (Date of cut flower senescence - date of harvest).

jWilting $=0$ or browning/drying $=1$.

iDerived by parent-offspring regression.

$\mathrm{h}\{\mathrm{k}[1+(\mathrm{n}-1) \mathrm{t}] / \mathrm{nN}\} ; \mathrm{k}=$ number of parents of each family, $\mathrm{N}=$ number of families giving paired observations, $\mathrm{n}=$ number of offspring observed for each family, $\mathrm{t}=$ intraclass correlation of siblings.

$\mathrm{g}[$ (Number of stoma) / (number of stoma + number of epidermal cells) per area $] \times 100$.

leaf area, which dropped from 0.48 and 0.58 in the $\mathrm{F}_{3}$ to 0.20 and 0.28 in the $\mathrm{F}_{5}$, respectively.

Environmental sensitivity can reduce heritabilities (Falconer and Mackay, 1996). Leaf area has been shown to vary with soil moisture in Pelargonium hortorum Ait. (geranium) (Metwally et al., 1971), light intensity in Sinapsis alba L. (white mustard) (Wild and Wolf, 1980), and was one of the most environmentally sensitive traits to date of seed sowing in A. majus (Rabinowitch et al., 1977). Ornamental quality is known to be environmentally sensitive to production (Rabinowitch et al., 1977) and post-production conditions (Halevy and Mayak, 1979; van der MeulenMuisers and van Oeveren, 1997). Traits measured in A. majus were affected by production conditions; however, buds at discard, PHL, and senescence symptom were affected by both production and post-production conditions. This experiment was designed to provide maximum resolution between genotypes for the later two 
Table 3. Phenotypic correlation coeffiecients ${ }^{\mathrm{z}}$ (above diagonal) and genotypic correlation coeffiecients ${ }^{\mathrm{y}}$ with respective standard errors ${ }^{\mathrm{x}}$ (below diagonal) between phenotypic traits in $\mathrm{F}_{5}$ families of Antirrhinum majus.

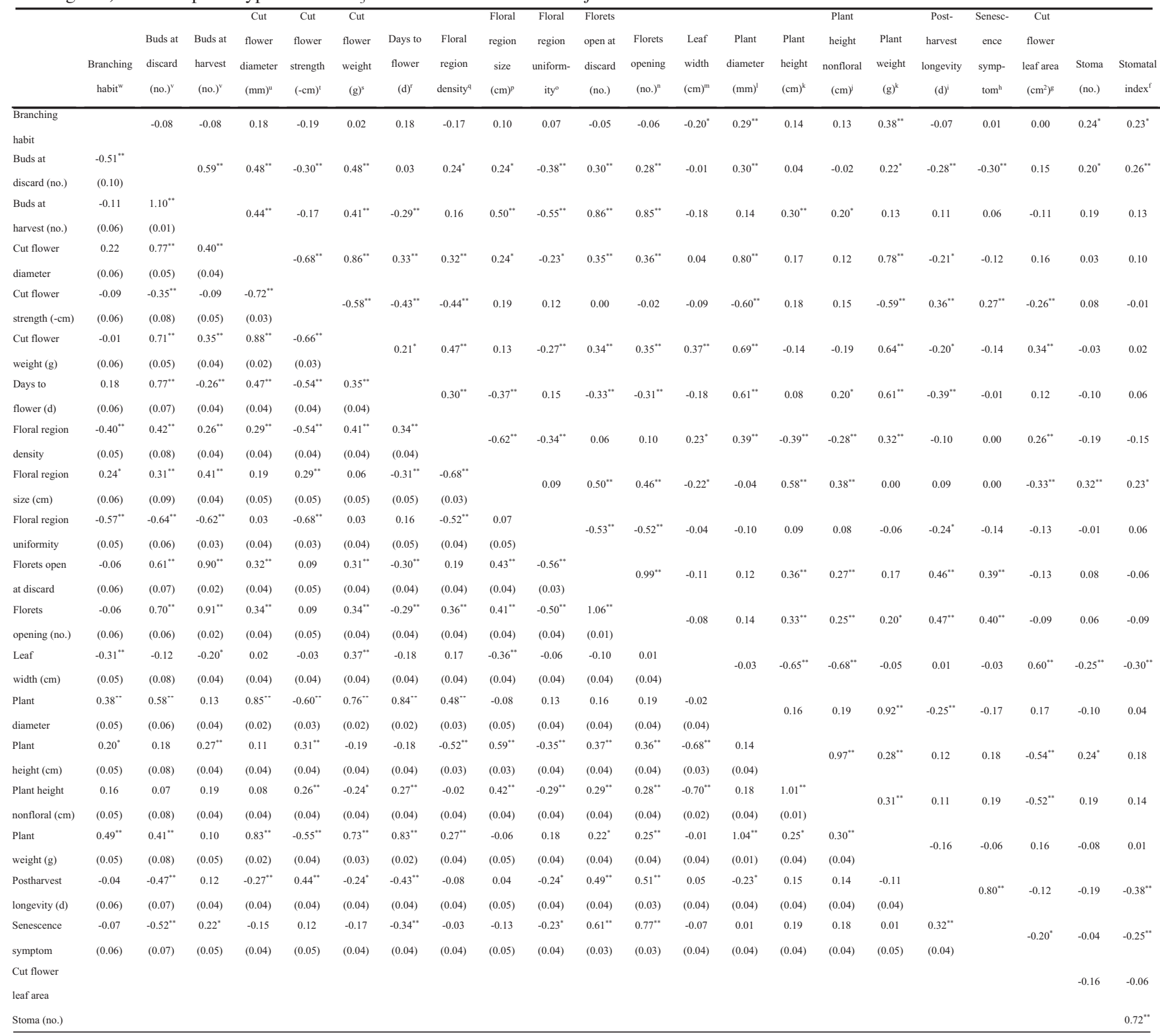

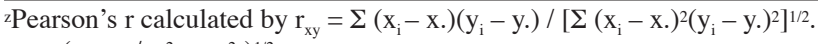

${ }^{\mathrm{y}_{\mathrm{A}}}=\left(\operatorname{cov}_{\mathrm{xy}} / \sigma_{\mathrm{x}}^{2}+\sigma^{2}\right)^{1 / 2}$

${ }^{x} \mathrm{SE}\left(\mathrm{r}_{\mathrm{A}}\right)=1-\mathrm{r}_{\mathrm{A}}{ }^{2} /(2)^{1 / 2}\left[\left\{\left(\sigma_{\mathrm{h} 2 \mathrm{x}}\right)\left(\sigma_{\mathrm{h} 2 \mathrm{y}}\right) / \mathrm{h}^{2}{ }_{\mathrm{x}} \mathrm{h}^{2}\right\}^{1 / 2}\right]$.

wBranching habit: $\sum \mathrm{k}_{\mathrm{i}} \mathrm{n}_{\mathrm{i}}$; where $\mathrm{k}=1$ (side branching $<10 \mathrm{~cm}$ in length), 2 (basal branching), 3 (side branching $>10 \mathrm{~cm}$ in length,

usually singular), 4 (crown branching), or 5 (branching with buds) and $n=$ number of nodes where branching occurred.

"Florets showing color before anthesis.

uAt $40 \mathrm{~cm}$ below lowest floret.

tDeviation in horizontal position.

sOf $40 \mathrm{~cm}$ stem below lowest floret with bottom $15 \mathrm{~cm}$ of leaves removed.

$\mathrm{r}$ (Date of harvest - date of seed sowing).

q[(Number of buds + number of florets) / (plant height - plant height nonfloral) at harvest].

$\mathrm{p}($ Plant height - plant height nonfloral).

-Visual scale $(1=$ excellent, 5 = very poor $)$.

n(Florets open at discard - florets at harvest).

mAt $40 \mathrm{~cm}$ below lowest floret.

'At soil line.

kSoil line to plant tip.

iSoil line to lowest floret.

i(Date of cut flower senescence - date of harvest).

hWilting $=0$ or browning/drying (1).

gOf 40 stem below lowest floret with bottom $15 \mathrm{~cm}$ of leaves removed.

$\mathrm{f}[($ Number of stoma) $/($ number of stoma + number of epidermal cells $)$ per area $)] \times 100$.

*,**Significant at $P<0.05$ or $P<0.01$, respectively. 
traits by minimizing the expected standard errors; no such consideration was given for buds at discard. Therefore, experimental control of error may partially explain the stability of heritability for PHL and senescence symptom and the drop in heritability for buds at discard. Environmental sensitivity of branching habit in A. majus (Rabinowitch et al., 1977) and lack of accuracy and/or consistency in trait quantification can also reduce heritabilities (Falconer and Mackay, 1996). Subjective quantification of the environmentally sensitive branching habit likely caused moderate $\mathrm{h}^{2}$ for $\mathrm{F}_{5}$ families $(0.41, \mathrm{CI}=0.23-0.55)$.

Narrow-sense heritability estimates for A. majus PHL, ranging 0.79 to 0.81 (Table 2), are higher than previously reported, 0.30 (Schroeder, 2000) and 0.41 (Martin, 2000); however, the estimates are considered more representative of genetic potential due to evaluation of larger and more genetically pure populations and more generations being utilized for derivation. Narrow-sense heritabilities for PHL reported here, though population specific, agree with estimates in Lilium L. (lily) 0.74 (van der MeulenMuisers et al., 1999) and Rosa L. (rose) 0.80 (De et al., 1999), but are higher than those reported for Gerbera Gmel. (gerbera daisy) 0.00 to 0.38 (Harding et al., 1981) and 0.28 (Wernett et al., 1996b). Moderate $\mathrm{h}^{2}$ for PHL are reported for $\mathrm{F}_{1}$ hybrids of Callistephus chinensis Nees (China aster) 0.59 (Patil and Rane, 1995), and backcrosses of D. caryophyllus, 0.51 to 0.59 (Burchi et al., 1999). PHL $\mathrm{h}^{2}$ disparity supports expected species and population variability and additionally, that estimate variability may be due to inbreds being evaluated in A. majus and clones in Lilium spp. and Rosa spp. vs. full- and half-sib families in Gerbera spp.

Narrow-sense heritability estimates reported here (Table 2 ) for plant phenotypic traits of this population of A. majus are similar to those found for $C$. chinensis for branching habit (0.47), days to flower (0.64), plant and floret height (0.75), buds at harvest (0.65), and plant and cut flower weight (0.67) (Patil and Rane, 1995). Narrow-sense heritability estimates reported here for plant height and days to flower agree with broad sense heritabilities given for H. annuum, 0.41 to 0.93 and 0.81 to 0.95 (Virk and Pooni, 1994) and for Cicer arietinum L. (chickpea) 0.62 and 0.71 (Moussa et al., 2000). Relatively high heritabilities suggest predictability of progeny from crosses of characterized parentage and that selection is possible and should be successful (Falconer and Mackay, 1996). Heritability estimates can be affected by species, population, environment, experimental design, sampling techniques, and complex interactions of these factors (Falconer and Mackay, 1996). Quality trait $\mathrm{h}^{2}$ estimates are presented acknowledging parental lines were not selected to deviate specifically for the examined quality traits. Information on $\mathrm{h}^{2}$ of ornamental quality traits is generally lacking in the literature; therefore, the information presented here on A. majus is to serve as a basis for future work and meanwhile as a guide to ornamental breeders.

Genotypic correlations between trait combinations vary from highly significant to nonexistent (Table 3 ). Utility of genetic correlations can be limited due to some traits being autocorrelated and subsequently these combinations show high and likely false correlations. Examples of suspect correlations include plant height and plant height nonfloral $(1.01 \pm 0.01)$, buds at discard and buds at harvest $(1.10 \pm 0.01)$, and florets open at discard with florets opening $(1.06 \pm 0.01)$. Less obvious examples confounded not by autocorrelations but by definition include buds at harvest with floral region uniformity, $0.62 \pm 0.03$, and florets open at discard,
$0.56 \pm 0.03$. Correlations of florets opening with PHL, $0.51 \pm$ 0.03 , and with senescence symptom, $0.77 \pm 0.03$, provide two more examples of definitional nonindependence. Finally, the negative correlations of cut flower strength with floral region density, $-0.54 \pm 0.04$, and with floral region uniformity, $-0.68 \pm$ 0.03 , are likely due to more buds and florets in the floral region putting comparatively unequal strain on the stem and, therefore, are autocorrelated.

Plant architecture traits including branching habit, cut flower weight, floral region size, plant height, plant height nonfloral, plant weight, cut flower diameter, and cut flower strength are often significantly and positively correlated suggesting an underlying pleotropic consequence of plant vigor. Floral region density is inversely correlated with floral region size, $-0.68 \pm$ 0.03 , suggesting increased internode length may reduce plant and floral quality characteristics. Inverse correlations between leaf width and plant height nonfloral, $-0.70 \pm 0.02$, as well as the inverse correlation of branching habit with buds at discard, $-0.51 \pm 0.10$, with floral region density, $-0.40 \pm 0.05$, and with floral region uniformity, $-0.57 \pm 0.05$, may reflect carbon and energy partitioning that subsequently detracts from ornamental cut flower quality.

PHL is of primary interest to this research and several correlations suggest plant architecture may have impacts upon PHL. Buds at discard is positively correlated to cut flower and plant diameter, cut flower weight and days to flower, $0.77 \pm 0.05,0.58 \pm$ $0.06,0.71 \pm 0.06$, and $0.77 \pm 0.07$, respectively. Interpreted, these positive correlations suggest increased stem diameter increases the number of florets failing to open postharvest. In addition, cut flower strength and days to flower are inversely related to PHL, $-0.44 \pm 0.04$ and $-0.43 \pm 0.44$, respectively, while cut flower diameter, strength, and weight are increased by days to flower, $0.47 \pm 0.04,0.54 \pm 0.04$, and $0.35 \pm 0.04$, respectively. Woodier plant stems are more prone to wilt (Jones et al., 1993) and likely contain more secondary growth including development of secondary xylem (Raven et al., 1992). Canny (1995, 1997a, 1997b, 1998) has shown that secondary xylem is less stable in water balance, being more prone to vascular occlusions and/or cavitations due to its larger interior diameter. These inverse correlations between PHL and other quality traits of interest may provide challenges to breeders as selection performed on PHL will lead to negative correlated responses in other traits (Falconer and Mackay, 1996). Populations can be screened for exceptions to negative correlations. Rare favorable combinations were found in evaluated A. majus populations.

Simultaneous selection for multiple quality traits is more effective than independent culling or tandem selection (Baker, 1986). Correlated response to selection addresses changes in trait values when a separate trait is selected (Falconer and Mackay, 1996). Due to the complex definition of quality and exhibited genetic correlations among ornamental quality traits, correlated response to selection is of concern when selecting for PHL (Falconer and Mackay, 1996). With PHL positively correlated to evaluated quality traits (Table 3 ) and existing population variability (Table 1), a simplistic situation for simultaneous selection for PHL and other traits exists. In other situations with negative genetic correlations, analogous variation is found within quality traits; therefore, simultaneous selection remains reasonable though caution is advised. Selection for simultaneous improvement of quality traits should be effective. 


\section{Literature Cited}

Baker, R.J. 1986. Selection indices in plant breeding. CRC Press, Boca Raton, Fla.

Bobisud, C.A. and H. Kamemoto. 1982. Selection and inbreeding in amphidiploid Dendrobium (Orchidaceae). J. Amer. Soc. Hort. Sci. 107:1024-1027.

Bradshaw, J.E., D. Todd, and R.N. Wilson. 2000. Use of tuber progeny tests for genetical studies as part of a potato (Solanum tuberosum subsp. tuberosum) breeding programme. Theor. Appl. Genet. 100:772-781.

Burchi, G., C. Bianchini, A. Mercuri, G. Foglia, D. Rosellini, and T. Schiva. 1999. Analysis of post-harvest flower life in a cross between carnation cultivars with different ethylene responses. J. Genet. Breeding 53:301-306.

Canny, M.J. 1995. A new theory for the ascent of sap-Cohesion supported by tissue pressure. Ann. Bot. 75:343-357.

Canny, M.J. 1997a. Vessel contents of leaves after excision-A test of Scholander's assumption. Amer. J. Bot. 84:1217-1222.

Canny, M.J. 1997b. Vessel contents of leaves after excision - Embolisms and refilling. Amer. J. Bot. 84:1223-1230.

Canny, M.J. 1998. Applications of the compensating pressure theory of water transport. Amer. J. Bot. 85:897-909.

De, L.C., S.D. Wahi, and S.K. Bhattacharjee. 1999. A post-harvest study of genetic divergence in cut roses. Indian J. Genet. 59:351-356.

Falconer, D.S. and T.F.C. Mackay. 1996. Introduction to quantitative genetics. $4^{\text {th }}$ ed. Addison Wesley Longman, Harlow Essex, England.

Hallauer, A.R. and J.B. Miranda. 1988. Quantitative genetics in maize Breeding. $2^{\text {nd }}$ ed. Iowa State Univ. Press, Ames.

Hallauer,A.R. and J.H. Sears. 1973. Changes in quantitative traits associated with inbreeding in a synthetic variety of maize. Crop Sci. 13:327-330.

Halevy, A.H. and S. Mayak. 1979. Senescence and postharvest physiology of cut flowers, Part I. Hort. Rev. 1:204-236.

Harding, J.T., B. Byrne and R.L. Nelson. 1981. Estimation of heritability and response to selection for cut-flower yield in gerbera. Euphytica 30:313-322.

Jones, R.B., J.D. Faragher, and W.G. van Doorn. 1993. Water relations of cut flowering branches of Thryptomene calycina (Lindl.) Stapf. (Myrtaceae). Postharvest Biol. Technol. 3:57-67.

Knapp, S.J., W.W. Stroup, and W.M. Ross. 1985. Exact confidence intervals for heritability on a progeny mean basis. Crop Sci. 25:192-194.

Lea, H.Z., G.M. Dunn, and D.W. Koch. 1977. Stomatal indexes in three ploidy levels of Bromus inermis Leyss. Crop Sci. 17:669-670.

Littell, R.C., G.A. Milliken, W.W. Stroup, and R.D. Wolfinger. 1996. SAS system for mixed models. SAS Inst., Cary, N.C.

Mackay, W.Aand T.D. Davis. 1998. 'Texas Sapphire' and 'Texas Ice' longstem bluebonnets (Lupinus harvardii). HortScience 33:348-349.

Marousky, F.J. and J.C. Raulston. 1970. Interaction of flower preservative components and light on fresh weight and longevity of snapdragon flowers. Proc. Fla. State Hort. Soc. 83:445-448.

Martin, W.J. 2000. Cut flower postharvest longevity and evaluation of correlated traits to postharvest longevity in advanced generations of Antirrhinum majus L. (snapdragon). M.S. Thesis, Univ. of Wisconsin-Madison.

Metwally, A.W., G.E. Beck, and B.E. Struckmeyer. 1971. Density and behavior of stomata of Pelargonium hortorum Ait. grown under three soil moisture regimes. J. Amer. Soc. Hort. Sci. 96:31-34.

Mitchell, R.J. and R.J. Shaw. 1993. Heritability of floral traits for the perennial wild flower Penstemon centranthifolius (Scrophulariaceae): Clones and crosses. Heredity 71:185-192.
Moussa, E.H., T. Millan, M.T. Moreno, and J. Gil. 2000. Genetic analysis of seed size, plant height, day to flower and seeds/plant by using both morphological and molecular markers in chickpea. J. Genet. Breeding 54:101-107.

Nell, T.A. 1992. Taking silver safely out of the longevity picture. Grower Talks, June: 35, 37, 39, 41-42.

Ohkawa, K., Y. Kasahara, and J.N. Suh. 1999. Mobility and effects on vase life of silver-containing compounds in cut rose flowers. HortScience 34:112-113.

Onozaki, T., H. Ikeda, and T. Yamaguchi. 2001. Genetic improvement of vase life of carnation flowers by crossing and selection. Sci. Hort. 87:107-120.

Patil, S.S.D. and D.A. Rane. 1995. Studies on heritability estimates in china aster. J. Maharashtra Agr. Univ. 20:137-138.

Rabinowitch, H.D., A.E. Arthur and C.L. Hedley. 1977. Biometrical analyses of some economically important characters in Antirrhinum majus L. Theor. Appl. Genet. 49:35-42.

Raven, P.H, R.F. Evert, and S.E. Eichhorn. 1992. Biology of plants: $5^{\text {th }}$ ed. Worth Publishers, New York.

Rogers, M.N. 1992. Snapdragons, p. 93-112. In: R.A. Larson (ed.). Introduction to floriculture. $2^{\text {nd }}$ ed. Academic, San Diego.

Sampson, J. 1961. A method of replicating dry or moist surfaces for examination by light microscopy. Nature 191:932-933.

Satterthwaite, F.E. 1946. An approximate distribution of estimates of variance components. Biometrics Bul. 2:110-114.

Schroeder, K.R. 1995. Inheritance of postharvest longevity of cut stems in Antirrhinum majus L., snapdragon. MS Thesis, Univ. of Wisconsin-Madison.

Schroeder, K.R. 2000. A study on the genetics and physiology of cut flowers postharvest longevity in Antirrhinum majus L. PhD Diss., Univ. of Wisconsin-Madison.

Schroeder, K.R. and D.P. Stimart. 2001. Genetic analysis of cutflower longevity in Antirrhinum majus L. J. Amer. Soc. Hort. Sci. 126:200-204.

Stieve, S.M. and D.P. Stimart. 1994. Genetic analysis of postharvest longevity in Antirrhinum majus L. HortScience 29:435. (Abstr.)

van der Meulen-Muisers, J.J.M., and J.C. van Oeveren. 1997. Influence of bulb stock origin, inflorescence harvest stage and postharvest evaluation conditions on cut flower longevity of Asiatic hybrid lilies. J. Amer. Soc. Hort. Sci. 122:368-372.

van der Meulen-Muisers, J.J.M., J.C. van Oeveren, J. Jansen, and J.M. van Tuyl. 1999. Genetic analysis of postharvest flower longevity in Asiatic hybrid lilies. Euphytica 107:149-157.

Virk, P.S. and H.S. Pooni. 1994. Genetic potential of selected sunflower crosses for producing early flowering recombinant inbred lines. J. Genet. Breeding 48:47-54.

Wernett, H.C., T.J. Sheehan, G.J. Wilfret, F.J. Marousky, P.M. Lyrene, and D.A. Knauft. 1996a. Postharvest longevity of cut-flower gerbera. I. Response to selection for vase life components. J. Amer. Soc. Hort. Sci. 121:216-221.

Wernett, H.C., G.J. Wilfret, T.J. Sheehan, F.G. Martin, T.L. White, G.L. Powell, and C. Wilcox. 1996b. Postharvest longevity of cutflower gerbera. II. Heritability of vase life. J. Amer. Soc. Hort. Sci. 121:222-224.

Wild, A. and G. Wolf. 1980. The effect of different light intensities on the frequency and size of stomata, the size of cells, the number, size and chlorophyll content of chloroplasts in the mesophyll and the guard cells during the ontogeny of primary leaves of Sinapsis alba. Zeitschrift für Pflanzenphysiologie 97:325-342. 